\title{
KLINIIK ARASTTIRMA
}

\section{CERRAHII VE CERRAHII DISSI KLINIIKLERDEKII ASISTTAN HEKIIMLERDE TƯKENMISSLIIK SENDROMU}

\author{
BURNOUT SYNDROME AMONG THE RESIDENT DOCTORS IN SURGICAL \\ AND NONSURGICAL CLINICS
}

\author{
Hüseyin CAN \\ Yusuf Adman GÜÇLÜ \\ Sellami DOĞAN \\ Mehtap Berrak ERKALELI
}

\section{ÖZIET}

AMAÇ: Cerrahi ve cerrahi dışı dallarda uzmanlık eğitimi alan asistan doktorların tükenmişlik sendromu açısından incelenerek, tükenmede rol alan etmenlerin değerlendirilmesi.

GEREÇ VE YÖNTEIM: İzmir Tepecik Eğitim ve Araştırma Hastanesinde 85'i cerrahi dışı ve 80'i cerrahi dalda uzmanlık eğitimi almakta olan toplam 165 asistan doktora Maslach Tükenmişlik Ölçeği ve sosyodemografik özelliklere ait 38 farklı etkeni sorgulayan bir anket uygulanmış ve yanıtları istatistiksel olarak değerlendirilmiştir. Duygusal tükenmişlik, duyarsızlaşma ve kişisel başarı duygusu düzeyleri düşük, orta ve yüksek olarak 3 grupta değerlendirilmiştir.

BULGULAR: Dahili dallardaki asistan doktorların \% 75,3'ünde duygusal tükenmişlik, \% 63,5'inde duyarsızlaşma düzeyi yüksek bulunmasına karşın sadece \% 11,8'inde kişisel başarı duygusu düşük bulundu. Cerrahi dallardaki asistan doktorların $\% 50$ 'sinde duygusal tükenmişlik, $\% 65^{\prime}$ inde duyarsızlaşma düzeyi yüksek bulunmasına karşın sadece $\% 8,8$ 'inde kişisel başarı duygusu düşük bulundu. Dahili dallarda duygusal tükenmişlik yaşayanların, cerrahi dallara göre anlamlı oranda fazla olduğu bulundu $(p<0,05)$. Her iki grup arasında duyarsızlaşma ve kişisel başarı açısından anlamlı fark bulunmadı $(p>0,05)$.

SONUÇ: Dahili ve cerrahi dallarda çalışan asistan hekimlerde duygusal tükenmişlik ve duyarsızlaşma oranlarının yüksek olduğu saptandı. Buna rağmen kişisel başarı duygusu düzeyinin henüz aynı ölçüde düşmediği belirlendi. Bu veriler hastanemizde çalışmanın yapıldığı alanlar başta olmak üzere tüm asistanların tükenmişliğini azaltmak için klinik ve hastane yönetimince gerekli önlemlerin alınması ve bu konuda asistanların desteklenmesi gerektiğini vurgulamaktadır.

Amahtar Sözcülkler: Maslach Tükenmişlik Ölçeği, Meslek hastalığı, Tıp Personeli, Tükenme Sendromu

\section{SUMIMARY}

AIM: A fact-finding study of burnout syndrome among assistant doctors who are specializing in internal and surgical and non-surgical clinics and evaluation of the causative factors involved.

MATERIAL AND METHOD: Maslach Burnout Inventory (MBI) and a questionnaire comprising 38 different sociodemographic characteristics were presented to a total of 165 residents working our hospital, 85 of whom were in

Tepecik Eğitim ve Araştırma Hastanesi Aile Hekimliği Bölümü, İMİR 
nonsurgical branches and 80 in surgical branches; and their answers were statistically evaluated. Emotional exhaustion, desensitization and the feeling personal accomplishment were evaluated in three levels as low, medium and high.

FINDINGS: Despite the fact that emotional exhaustion and desensitization levels were found to be high among the assistant doctors in non-surgical branches, $75.3 \%$ and $63.5 \%$ respectively, feeling of personal accomplishment was low and stood only at $11.8 \%$. In the surgical branches, emotional exhaustion and desensitization levels were again high, $50 \%$ and $65 \%$, respectively, as opposed to a low level of feeling of personal accomplishment which stood only at $8.8 \%$. It was found that the level of emotional exhaustion experienced by those in the non-surgical branches was significantly higher in comparison to that experienced in the surgical branches $(p<0,05)$. There was no significant difference between the two groups from the viewpoint of desensitization and the feeling of personal accomplishment $(p>0,05)$.

CONCLUSION: It was found that the ratio of emotional exhaustion and desensitization was high among the assistant doctors in both the surgical and non-surgical branches. However, the feeling of personal accomplishment had not shown a proportionate lessening at the moment. These findings emphasize the need to take appropriate steps both by the clinics and the hospital administration to reduce and provide support against burnout syndrome, not only in the branches where this study was carried out but also probably in all the branches.

Key words: Burnout syndrome, Maslach Burnout Inventory, Medical personnel, Occupational health

\section{GIIIIŞ}

Tükenmişlik (burnout) sendromu; bireylerin, işleri gereği karşılaştıkları insanlara karşı duyarsızlaşmaları, duygusal açıdan kendilerini tükenmiş hissetmeleri, kişisel başarı ve yeterlilik duygularında azalma șeklinde kendini gösteren bir sendromdur(1). Hemen her meslek grubunda yaşanmasına rağmen, daha çok insanlarla yüz yüze ilişki içerisinde olan sağlık çalışanlarında, özellikle de hekimlerde yoğun görülmektedir (2-4).

Ölümcül olabilen hastalıklarla uğraşmak, insan yaşamı ile ilgili önemli kararlar vermek, bu kararların ciddi sonuçları ile yüz yüze olmak, sürekli hatadan kaçınmaya çalışmak, gerektiğinde hasta ve yakınlarına duygusal destek vermek zorunda kalmak gibi nedenler tükenmişliğe neden olmaktadır. Ayrıca düzensiz ve uzun mesai saatleri, hasta yoğunluğu, yoğun çalışma temposu, zamana karşı yarış, sayıca ve kalite açısından yetersiz yardımcılarla çalışmak, rol belirsizliği, sürekli yenilikleri izleme gerekliliği, hem kendisinin hem de aile ve çevresinin beklentilerinin yüksek olması, ekonomik kaygılar ve bu sorunlarla başa çımaya çalışırken kendisine ve özel yaşamına yeterince zaman ayıramama gibi nedenler de tükenmişliğe neden olan diğer etmenlerdir (5-8).

Tükenmişlik, bireysel ve kurumsal alanda ciddi sorunlara neden olabilmektedir. Yapılan araştırmalar tükenmişliğin hem fiziksel sağlıkla hem de çökkünlük ve kaygı gibi psikiyatrik problemlerle ilişkisini ortaya koymaktadır. Yoğun tükenmişlik durumu psikosomatik bozukluklara, evlilik sorunlarına, sigara, alkol ve madde kullanımına, aile ve sosyal yaşantıda sorunlara neden olabilmektedir. Kurumsal açıdan ise tükenmişlik, çalışanların işe geç gelmesi, işi önemsememesi, işi aksatması, işten erken ayrılması, sık rapor alması, işi bırakması ve bunun yanısıra işte yeniliklerin, yapıcı eleştirilerin, üretkenliğin ve yaratıcı girişimlerin kısıtlılı̆ğ gibi sorunlarla kendini göstermektedir $(6,8-10)$.

Bu çalışmada dahili ve cerrahi dallarda uzmanlık eğitimi almakta olan asistan hekimler ele alınarak tükenmişlik sendromu açısından ne durumda oldukları incelenmiș, bu sendromun oluşumunda rol alan etmenler değerlendirilmiştir.

\section{GEREÇ VE YÖNTEM}

Kesitsel tipteki bu çalışma, İzmir Tepecik Eğitim ve Araştırma Hastanesi'nde dahili ve cerrahi branşlarda tıpta uzmanlık eğitimi almakta olan asistan doktorlar arasında yapıldı. Dahili branşlarda 85, cerrahi branşlarda 80 olmak üzere toplam 165 asistan doktora ulaşılarak, araştırma anket formları dolduruldu ve değerlendirmeye alındı.

Veri toplama aracı olarak Maslach Tükenmişlik Ölçeği (MTÖ) ve sosyodemografik özelliklerle ilgili soruları içeren bir anket formu kullanılmıştır. MTÖ, Christine Maslach tarafindan geliştirilmiş ve literatüre girmiştir. Bu ölçeğin ülkemizde geçerlilik ve güvenilirlik çalışması Ergin (1992) tarafindan yapılmıştır. MTÖ, üç alt ölçek ve yirmi iki maddeden oluşmaktadır. Alt ölçekler; Duygusal Tükenme (DT), Duyarsızlaşma (D) ve Kişisel Başarı Duygusu (KB) bölümlerinden oluşmaktadır (Maslach ve Jackson 1986). 
Duygusal Tükenme alt ölçeği, iş hayatında aşırı derecede psikolojik ve duygusal isteklerle karşılaşmaktan dolayı yaşanan enerjinin bitmesi durumunu değerlendirir. Bu alt boyutta yorgunluk, bikkınlık ve duygusal enerjinin azalması ile ilgili 8 madde yer almaktadır. Duyarsızlaşma alt ölçeği, bireyin bakım ve hizmet verdiklerine karşı, duygudan yoksun bir biçimde, bireylerin kendine özgü birer varlık olduklarını dikkate almaksızın davranmalarını değerlendirir. Altı maddeden oluşmaktadır. Kişisel Başarı Duygusunda Azalma alt ölçeği, insanlarla yüz yüze çalışılan mesleklerde kişinin kendisini işinde yeterli ve başarılı hissetmesi durumunu değerlendirmektedir. Bu ölçek 8 maddeden oluşmaktadır.(11)

Maslach Tükenmişlik Ölçeği'nde puanlama sonucunda alt boyut puanları elde edilmektedir. DT ve D alt boyut puanları, her madde için 1: hiçbir zaman, 6 : her zaman olarak 7'li Likert tipi derecelemeye göre değerlendirilerek elde edilmektedir. KB ise bunun tam tersi olacak şekilde değerlendirilmektedir. Böylece tüm alt boyutlardan alınan puan yükseldikçe tükenmişliğin yükseldiği kabul edilmektedir.(11)

$\mathrm{Bu}$ alanda yapılan çalışmalar incelendiğinde tükenmişliğin düşük, orta, yüksek düzeylerde yaşanan duygu olduğu ve sürekli bir değişken olarak kavramlaştığı görülmektedir. Alt ölçeklerden elde edilen puanlar için sınır değeri olmadığından tükenme var ya da yok biçiminde bir ayırım yapılamamaktadır. Tükenmişliği yaşamakta olan bireylerde DT ve D puanlarının yüksek, KB puanlarının düşük olması beklenmektedir. Tükenmişliğin, bu üç yönü arasındaki ilişkiyle ilgili olarak, her alt ölçeğin puanı ayrı olarak değerlendirilmekte ve tek bir toplam puanla birleştirilmemektedir, sonuç olarak her birey için üç ayrı puan hesaplanmaktadır $(1,12)$.

Çalışmamızda bu ölçek aracılı̆̆ıyla dahili ve cerrahi dallardaki asistan hekimlerde tükenmişlik sendromu ile ilgili olarak, duygusal tükenme, duyarsızlaşma, kişisel başarı boyutlarındaki puanlar saptanmaya çalışıldı. Asistan hekimlerin tükenmişlik durumları ile ilişkili olarak DT, D, KB puanları ile anket formundaki, tükenmişlik sendromuna sebep olabileceği öngörülen sosyodemografik bağımsız değişkenler arasındaki ilişki incelendi. İstatistiksel analizler için SPSS (Statistical Package for Social Sciences) for Windows 16.0 programı kullanıldı. Tanımlayıcı istatistiksel metotların (ortalama, standart sapma, yüzde) yanı sıra niteliksel verilerin gruplar arası karşılaştırılmasında çok gözlü ki kare ilişki testi ve dört gözlü ki kare iliş̧i testi istatistiksel analizi kullanıldı. Niceliksel verilerin gruplar arası karşılaştırılmasında ise tek yönlü varyans analizi kullanıldı. Sonuçlar \% 95 güven aralığında $p<0,05$ düzeyinde istatistiksel olarak anlaml olarak değerlendirildi.

\section{BULGULAR}

Çalışmamıza İzmir Tepecik Eğitim Araştırma Hastanesi'nde cerrahi ve cerrahi olmayan dallarda uzmanlık eğitimi alan toplam 165 asistan hekim alınd. Bunlarn 85'i $(\% 51,5)$ dahili dallarda, 80'i $(\% 48,5)$ ise cerrahi dallarda eğitim almakta idi. Hastane dışı rotasyon nedeniyle bölümlerinde bulunmayan asistan hekimler çalışmaya alınmadı. Olguların demografik özellikleri incelendiğinde cerrahi olmayan dallarda kadınların erkeklere göre daha fazla olduğu, başka bir ifadeyle cerrahi dallarda erkeklerin kadınlara göre daha yüksek düzeyde olduğu saptandı $(p=0,000)$. Ancak yaş ortalaması ve medeni durumlarına göre dağılım incelendiğinde anlamlı bir fark bulunamadı. $\mathrm{p}=0,353 ; \mathrm{p}=0,110)$ (Tablo 1).

Cerrahi dallardaki hekimlerin bölümünü isteyerek seçme ve dalının hekimlik açısından saygınlığının daha fazla olduğunu düşünme düzeyinin cerrahi olmayan dallara göre daha yüksek, başka bir dal seçme isteğinin ise daha düşük olduğu saptandı $(p=0,001)$. Dallara göre işyeri doyumu ve çalışma koşulları incelendiğinde gruplar arası anlamlı bir farkl11ı bulunmad $(p=0,563)$. Cerrahi olmayan dallardaki hekimlerin \% 75,3'ünün, cerrahi dallardaki hekimlerin $\% 78,8^{\prime}$ inin tıp fakültesine girerken karş1laşacakları mesleki zorluklara dair bilgi sahibi olmadıkları saptandı. Ancak iki grup arasındaki farklılık istatistiksel olarak anlamlı değildi $(p=0,712)$. Cerrahi ve cerrahi olmayan dallardaki asistan hekimlerin büyük çoğunluğu iş dışında diğer sosyal etkinliklere zaman ayıramadığını bildirirken, bu durum açısından iki gurup arasında anlamlı bir farklılık bulunmadı $(\mathrm{p}=0,843)$.

Araştırmaya katılan asistan hekimlerin duygusal tükenmişlik, duyarsızlaşma ve kişisel başarı puanları daha yüksek bulundu. Cerrahi olmayan dallardaki asistan doktorların, cerrahi dallardakilere göre daha yüksek düzeyde duygusal tükenmişlik yaşadığı saptandı $(p=0,002)$. Ancak iki grup arasında duyarsızlaşma düzeyi ve kişisel başarı düzeyi açısından anlamlı fark saptanmadı $(p=0,689 ; p=0,782)$ (Tablo 2$)$. 
Tablo 1. Dallara Göre Demografik Özellikler ve Dalla İlgili Düşüncelerin Dağılımı

\begin{tabular}{|c|c|c|c|c|}
\hline & & $\begin{array}{l}\text { Cerrahi } \\
\text { olmayan }\end{array}$ & Cerrahi & $\mathrm{p}$ \\
\hline \multirow[t]{3}{*}{ Cinsiyet $(\mathrm{s} / \%)$} & & & & $0,000^{1 *}$ \\
\hline & Erkek & $36 / 42,4$ & $61 / 76,2$ & \\
\hline & Kadin & $49 / 57,6$ & $19 / 23,8$ & \\
\hline \multirow[t]{5}{*}{ Yaş (yıl) } & & & & $0,353^{2}$ \\
\hline & Ortalama & 29,37 & 28,95 & \\
\hline & SS & 3,24 & 2,57 & \\
\hline & En az & 24 & 25 & \\
\hline & En çok & 44 & 35 & \\
\hline \multirow[t]{4}{*}{ Medeni Durum (s/\%) } & & & & $0,110^{3}$ \\
\hline & Evli & $53 / 62,4$ & $37 / 46,2$ & \\
\hline & Bekar & $31 / 36,5$ & $41 / 51,2$ & \\
\hline & Boşanmış & $1 / 1,2$ & $2 / 2,5$ & \\
\hline \multirow[t]{3}{*}{ Bölümünü isteyerek Seçme (s/\%) } & & & & $0,001^{1 *}$ \\
\hline & Evet & $46 / 54,1$ & $69 / 86,2$ & \\
\hline & Hayır & $39 / 45,9$ & $11 / 13,8$ & \\
\hline \multirow[t]{3}{*}{ Başka bir Bölüm İsteği (s/\%) } & & & & $0,003^{1 *}$ \\
\hline & Evet & $66 / 77,6$ & $44 / 55,0$ & \\
\hline & Hayır & $19 / 22,4$ & $36 / 45,0$ & \\
\hline \multirow[t]{3}{*}{ Uzmanlığın Geleceği İle İlgilli Düşünce (s/\%) } & & & & $0,117^{1}$ \\
\hline & Olumlu & $30 / 35,3$ & $38 / 47,5$ & \\
\hline & Olumsuz & $55 / 64,7$ & $42 / 52,5$ & \\
\hline \multirow[t]{3}{*}{ Dalın Hekimlik Çevresinde Saygunlığı (s/\%) } & & & & $0,001^{1 *}$ \\
\hline & Olumlu & $29 / 34,1$ & $50 / 62,5$ & \\
\hline & Olumsuz & $56 / 65,9$ & $30 / 37,5$ & \\
\hline
\end{tabular}

' Fisher Ki kare $\quad * p<0,05$ düzeyinde istatistiksel olarak anlamlı

${ }^{2} t$ testi s: kişi sayısı

${ }^{3}$ Pearson Ki kare

Tablo 2. Cerrahi ve Cerrahi olmayan Dallardaki Asistan Hekimlerdeki Tükenmişlik Düzeyi

\begin{tabular}{|c|c|c|c|c|}
\hline & & Cerrahi olmayan s $(\%)$ & Cerrahis $(\%)$ & $p$ \\
\hline \multirow[t]{4}{*}{ Duygusal Tükenmişlik } & & & & $0,002^{1 *}$ \\
\hline & Düşük & $8(9,4)$ & $10(12,5)$ & \\
\hline & Orta & $13(15,3)$ & $30(37,5)$ & \\
\hline & Yüksek & $64(75,3)$ & $40(50,0)$ & \\
\hline \multirow[t]{4}{*}{ Duyarsızlaşma } & & & & $0,689^{1}$ \\
\hline & Düşük & $10(11,8)$ & $12(15,0)$ & \\
\hline & Orta & $21(24,7)$ & $16(20,0)$ & \\
\hline & Yüksek & $54(63,5)$ & $52(65,0)$ & \\
\hline \multirow[t]{4}{*}{ Kişisel Başarı Duygusu } & & & & $0,782^{\prime}$ \\
\hline & Düşük & $10(11,8)$ & $7(8,8)$ & \\
\hline & Orta & $26(30,6)$ & $27(33,8)$ & \\
\hline & Yüksek & $49(57,6)$ & $46(57,5)$ & \\
\hline
\end{tabular}
' Pearson ki kare $p<0,05$ düzeyinde istatistiksel olarak anlamlı
s: kişi sayısı

Araştırmaya katılan asistan hekimlerde genç yaşlarda, bir başka deyişle mesleğinin ilk yıllarında olanlarda duygusal tükenmişlik düzeyi yüksek saptandı. Cerrahi olmayan dallardaki asistan hekimlerde duygusal tükenmişlik ve duyarsızlaşma düzeylerinin ilerleyen yaşlarda daha düşük düzeyde olduğu saptandı $(p=0,001)$. Bu hekimlerde duygusal tükenmişlik puanları, kadınlarda erkeklere göre daha yüksek saptandı. Duygusal tükenmişlik ile cinsiyet arasındaki ilişki istatistiksel olarak anlamlı saptanmadi ( $\mathrm{p}=0,841$ ) (Tablo 3 ). 
Tablo 3. Cerrahi ve Cerrahi olmayan Dallarda Duygusal Tükenmişlik (DT) ile Yaş-Cinsiyet İlișkisi

\begin{tabular}{|c|c|c|c|c|c|c|c|c|}
\hline & & & Yas (vil) & & & & Cinsiyet & \\
\hline & & s & Ortalama & SS & $\mathrm{p}$ & Erkek s (\%) & Kadin s $(\%)$ & $\mathrm{p}$ \\
\hline \multirow[t]{4}{*}{ Cerrahi olmavan Dal-DT } & & & & & $0,00 I^{1 *}$ & & & $0,841^{2}$ \\
\hline & Düşük & 8 & 34,12 & 4,70 & & $4(50,0)$ & $4(50,0)$ & \\
\hline & Orta & 13 & 30,23 & 3,51 & & $6(46,2)$ & $7(53,8)$ & \\
\hline & Yüksek & 64 & 28,60 & 2,36 & & $26(40,8)$ & $38(59,4)$ & \\
\hline \multirow[t]{4}{*}{ Cerrahi Dal-DT } & & & & & $0,658^{1}$ & & & $0,009^{2 *}$ \\
\hline & Düşük & 10 & 30,1 & 3,03 & & $5(50,0)$ & $5(50,0)$ & \\
\hline & Orta & 30 & 29,96 & 2,70 & & $28(93,3)$ & $2(6,7)$ & \\
\hline & Yüksek & 40 & 28,90 & 1,90 & & $28(70,0)$ & $12(30,0)$ & \\
\hline
\end{tabular}

'Tek yönlü Anova $\quad * p<0,05$ düzeyinde istatistiksel olarak anlamlı
2 Pearson chi square

Tablo 4. Cerrahi ve Cerrahi olmayan Dallarda Duyarsızlaşma (D) ile Yaş-Cinsiyet Illişsisi

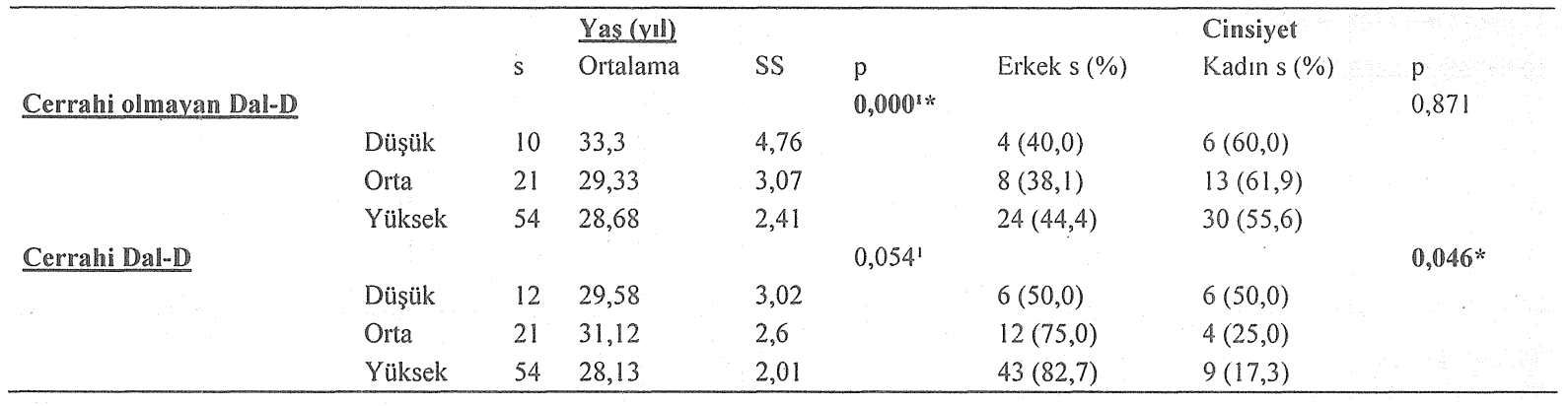

' Tek yönlü Anova $\quad * p<0,05$ düzeyinde istatistiksel olarak anlamlı

${ }^{2}$ Pearson chi square s: kişis sayısı

Cerrahi dallardaki asistan hekimlerde ise duygusal tükenmişlik, duyarsızlaşma düzeyleri ile yaş arasındaki ilişki istiksel olarak anlamlı saptanmadı $(p=0,658)$ (Tablo 3-4). Bu hekimlerde duygusal tükenmişlik, erkeklerde kadınlara göre daha fazla saptandı. Duygusal tükenmişlik düzeyi ile cinsiyet arasındaki ilişki istatistiksel olarak anlamli idi $(p=0,009)$ (Tablo 3$)$.

Araştırmaya katılan cerrahi olmayan dallardaki asistan hekimlerde duyarsızlaşma kadınlarda erkeklere göre, Cerrahi dallardaki asistan hekimlerde ise duyarsızlaşma erkeklerde kadınlara göre daha yüksek saptandı. Duyarsızlaşma düzeyi ile cinsiyet arasındaki ilişki istatistiksel olarak anlamlı saptanmad $(p=0,871)$ (Tablo 3).

Cerrahi olmayan dallarda duygusal tükenmişlik düzeyi yüksek olan asistan doktorlarin seçtikleri bölüme istemeyerek gelenlerin, isteyerek gelenlere göre daha fazla olduğu ve bu grupta uzmanlık eğitimi aldıkları dalın geleceği hakkında olumsuz düşünenlerin olumlu düşünenlere göre daha fazla olduğu saptanmıştır $(\mathrm{p}=0,002)$.

Cerrahi dallardaki duygusal tükenmişlik düzeyi yüksek olan asistan hekimlerde başka bölüm yapmak isteyenlerin, istemeyenlere göre daha fazla olması; uzmanlık eğitimi aldıkları dalın saygınlığı hakkında olumsuz düşünenlerin olumlu düşünenlere göre daha fazla olduğu saptanmıştır. $(p=0,043)$

Cerrahi olmayan dallardaki asistan hekimlerin bölümlerinden memnuniyetinin cerrahi dallara göre daha az düzeyde olması, kendi dallarından istifa etmeyi cerrahi dallara göre daha yüksek düzeyde düşünmeleri, yine bu hekimlerin uzman olduktan sonra aym hastane çalışma isteklerinin cerrahi dallardakilere göre daha yüksek düzeyde olması istatistiksel olarak anlamlı idi $(p=0,042, p=0,038, p=0,034)$ (Tablo 5). 
Tablo 5: Dallara Göre Asistan Hekimlerin Uzmanlık Dalı ve Uzmanlık Sonrası lle İlgili Düşünceleri

\begin{tabular}{|c|c|c|c|c|}
\hline & & $\frac{\frac{\text { Cerrahi }}{\text { olmayan }}}{\mathrm{s}(\%)}$ & $\frac{\text { Cerrahi }}{\mathrm{s}(\%)}$ & $\mathrm{p}$ \\
\hline \multicolumn{5}{|l|}{ Uzmanlık Dalından } \\
\hline \multirow[t]{3}{*}{ Memnunivet } & & & & $0,042^{1 *}$ \\
\hline & Evet & $38(44,7)$ & $48(60,0)$ & \\
\hline & Hayır & $47(55,3)$ & $33(40,0)$ & \\
\hline \multicolumn{5}{|l|}{ Dalından IIstifayı } \\
\hline \multirow[t]{3}{*}{ Düsünme } & & & & $0,038^{1 *}$ \\
\hline & Evet & $58(68,2)$ & $41(51,2)$ & \\
\hline & Hayır & $27(31,8)$ & $39(49,8)$ & \\
\hline \multicolumn{5}{|l|}{ Uzman Olunca Aymı } \\
\hline \multirow[t]{3}{*}{ Hastanede Calısma Ísteği } & & & & $0,034^{1 *}$ \\
\hline & Evet & $38(44,7)$ & $29(36,2)$ & \\
\hline & Hayır & $47(55,3)$ & $51(63,8)$ & \\
\hline \multicolumn{5}{|l|}{ Uzman Olduktan Sonra } \\
\hline \multirow[t]{6}{*}{ Callsmak istenen yer } & & & & $0,384^{2}$ \\
\hline & Üniversite & $14(16,5)$ & $22(27,5)$ & \\
\hline & Eğitim Araştırma & $31(36,5)$ & $28(35,0)$ & \\
\hline & Devlet hast. & $26(30,6)$ & $17(21,2)$ & \\
\hline & Özel Hast. & $13(15,3)$ & $11(13,8)$ & \\
\hline & Hiçbiri & $1(1,2)$ & $2(2,5)$ & \\
\hline
\end{tabular}

\section{TARTISSMA}

Cerrahi ve cerrahi olmayan dallarda uzmanlık eğitimi almakta olan asistan doktorların ele alınarak tükenmişlik sendromu açısından ne durumda oldukları incelenen çalışmamızda, bu sendromun oluşumunda rol alan etmenler değerlendirmeye çalışılmıştır.

Çalışmamızda cerrahi dalların erkekler tarafından daha fazla yeğlendiği belirlendi. Cerrahi olmayan dallarda asistanlık yapan hekimlerin duygusal tükenmişlik düzeyleri cerrahi dallarda asistanlık yapanlardan daha yüksektir. Bunun sebebi, cerrahi olmayan dalların bayanlar tarafindan daha fazla yeğlenmesi ve yapılan çalışmalarda kadınların erkeklere göre daha fazla duygusal tükenmişlik yaşaması olabilir (12-19). Çalışmamızda da literatür ile uyumlu bulgular elde edilmiştir. Bu durumun bir başka nedeni de cerrahi olmayan dallardaki asistan doktorların cerrahi dallardaki asistan doktorlara göre daha fazla oranda bölümlerini istemeyerek seçmeleri, bir başka bölüm istemeleri ve hekim toplumunda dallarinin sayginlık durumu hakkında olumsuz düşünmeleri olabilir. Cer- rahi olmayan dallardaki asistan hekimlerin istatistiksel anlamlı oranda dallarından memnuniyetinin cerrahi dallara göre daha az düzeyde olması, dalından ayrılmayı cerrahi dallara göre daha yüksek düzeyde düşünmesi de bu durumu açıklamaktadır.

Hekimlerin dallarıyla ilgili düşüncelerinde; her iki dal için de asistan doktorların yarısından fazlasının başka bir bölüm istemesi dikkat çekici bir bulgu olarak göze çarpmaktadır. Dikkat çeken diğer bir nokta da cerrahi olmayan dal doktorlarının \% 85,5'inin ülkenin uzmanlik geleceğiyle ilgili olumsuz fikir belirtmiş olmalarıdır. Cerrahi dallarda ise duygusal tükenmişlik düzeyi yüksek olan asistan doktorların hekimlik çevresinde saygınlık durumu hakkında olumsuz düşünenlerin istatistiksel anlamlı olarak daha fazla oranda olduğu saptandı. Yine cerrahi dallarda duygusal tükenmişlik düzeyi yüksek olan asistan doktorların dalı dışında başka bir bölümde asistanlı yapmak isteyenlerin, dalı dışında başka bir bölümde asistanlık yapmak istemeyenlere göre daha fazla olması istatistiksel olarak anlamlı saptandı. Her iki dal doktorları için de, tüken- 
mişlik nedeniyle mi başka bir bölüm isteği ortaya çımmakta ya da başka bir bölüm isteği nedeniyle mi tükenmişlik durumunun meydana geldiğinin nedenlerinin incelenmesi gerektiği düşüncesindeyiz.

Dallara Göre İşyeri Memnuniyeti ve Çalışma Şartları incelendiğinde her iki grupta da asistan doktorlarm yarısından fazlasının işyerinden memnun olmadıkları ve nöbet sonrası izin kullanmadıkları saptandı. İşyeri memnuniyetinin, nöbet sonrası izin kullanmamanın, hekimlerin hastaları ya da meslektaşları tarafindan takdir edilmediği düşüncelerinin tükenmişlikle ilişkili olduğu düşüncesindeyiz. Ayrıca her iki dal doktorlarının yükssek oranda hastane dışı etkinliklere zaman ayıramadıklarını belirtmiş olmaları da diğer bir tükenmişlik nedeni olabileceğini düşündürmektedir.

Çalışmamızda dikkat çeken diğer bir nokta da cerrahi dallardaki erkek asistanların kadın asistanlara göre istatistiksel olarak anlamlı oranda daha fazla tükenmişlik yaşadığıdır. Literatürde buna benzer olarak, Maslach ve Jacson çalısmalarında tükenmişliğin duyarsizlaşma ve kişisel başarıda düşme duygusunu erkeklerin daha fazla yaşadığını ortaya koymuşlardır $(1,14)$. Ergin ve arkadaşlarının yaptığı bir çalışmada da doktor ve hemşireler için benzer sonuçlar elde edilmiştir (Hacettepe Üniversitesi 1992).

Asistanların tükenmişlik ve yaş ilişkileri incelendiğinde cerrahi olmayan dallardaki asistanların yaș ortalaması arttıkça tükenmişliğin istatistiksel anlamlı olarak azaldığı görülmektedir. Cerrahi dallardaki asistanlarda da yaş ortalamasının artmasıyla tükenmişliğin azaldığı görülmektedir ancak istatistiksel olarak anlamlılık saptanmamışı̆ır. Yapılan çalışmalarda yaş, çalışma süresi ve mesleki kıdem ile tükenmişlik düzeyi arasında olumsuz bir ilişkinin olduğu, genç ve deneyimsiz çalışanlarda tükenmenin daha fazla olduğu görülmüş, bu durum işe yeni başlayan bireylerin iş konusunda çok daha heyecanlı ve istekli olmaları nedeniyle daha fazla enerji harcayarak daha kisa zamanda yorulmalarına da bağlanmıştır (1,6,19-21). Çalışmamızda da cerrahi olmayan dal asistanları için benzer sonuçlar elde edilmiştir. Cerrahi dal asistan doktorlarında da yaşın artmasıyla tükenmişliğin azaldığı görülse de istatistiksel olarak anlamlılık saptanmadı. Veriler incelendiğinde cerrahi olmayan dalların en yüksek yaş ortalaması grubunun 34,12 olduğu, cerrahi dalların en yüksek yaş ortalaması grubunun ise 30,1 olmasından kaynaklanan yaş farkı nedeniyle bu sonuca varılmış olabilir. İșe yeni başlayan bireylerde tükenmişliğin daha fazla görülmesinin bir diğer sebebi ise, yeni işin getirdiği rol ve sorumlulukların karmaşası ve mesleğe bağlılığın henüz oluşmamış olması, iş hayatı ile özel yaşam arasında dengeli bir ilişki kuramamak şeklinde belirtilmiştir. $(20,21)$

Her iki daldaki asistan doktorların duyarsızlaşma oranlarına bakıldığında hem cerrahi olmayan hem de cerrahi dal doktorlarınin yarısından fazlasinda duyarsızlaşma düzeyi yüksek saptandı. Dallar arası duyarsızlaşma oranında ise istatistiksel olarak anlamlı farklilık saptanmadi. Yine duyarsızlaşma ile yaş ilişkilerine bakıldığında cerrahi olmayan dallarda yaşın artmasıyla duyarsızlaşmanın istatistiksel anlamlı oranda azaldığı görülmüștür. Cerrahi dallarda ise tükenmişlik ve yaş ilişkisine benzer şekilde yaş ve duyarsızlaşma arasında ilişki kurulamamıştır. Ancak cerrahi olmayan dallarda kadin, cerrahi dallarda ise erkek asistan doktorlarm istatistiksel olarak daha fazla oranda duyarsızlaşmış olması, yine cerrahi olmayan dalların kadınlar tarafindan daha fazla yeğlenmesi ve yapılan çalışmalarda kadınların erkeklere göre daha fazla duygusal tükenmişlik yaşaması nedeniyle açıllanabilir (12,13-19,20).

Çalışmamızdaki önemli bir eksiklik klinik düzeyde depresyonu olabilecek deneklerin dışlanamayışıdır.

İnsanlarla yüz yüze ilişki gerektiren mesleklerde daha fazla tükenmişlik görülmesi, cerrahi olmayan dallardaki asistan doktorların hastalar ve diğer meslektaşlarıyla daha fazla iletişime girdikleri gerçeğine paralel olarak cerrahi olmayan dallardaki asistanlarm duygusal tükenmişliğinin fazla olmasının nedenini kısmen açıklayabilir (1). İnsanlarla çalışan profesyonellerde, insanlara karşı duyulan sorumluluğun, nesnelere karşı duyulan sorumluluktan daha fazla olması nedeniyle, bu kişilerde tükenme riskinin daha yüksek olduğu çeşitli araştırmalarla ortaya konulmuştur $(19,22)$. Bu nedenle tükenmişlik daha çok doğrudan insana hizmet eden hizmet kalitesinde insan etmeninin çok önemli bir yere sahip olduğu mesleklerde özellikle de sağllk çalışanlarında daha yoğun görülmektedir (Ergin C, 1992).

\section{SONUC}

Cerrahi olmayan dallardaki asistan doktorların duygusal tükenmişlik oranının cerrahi dallardaki asistan doktorlara oranla daha fazla olduğu saptanmıştır. Cerrahi olmayan branşların kadın hekimler tarafindan daha fazla yeğlendiği ve kadınlarda tükenmişlik ora- 
nının daha yüksek olduğu saptanmıștır. Bu durumu, cerrahi olmayan gruptaki evli oranının daha yüksek oluşu ve ülkemizdeki yaşam kültüründe kadının çalıssa bile evde erkekten çok daha fazla yorulduğu gerçeği ile açıklamak mümkündür. Cerrahi ve cerrahi olmayan dallarda duyarsızlaşmanın yüksek olduğu ve kişisel başarının henüz aynı ölçüde düşmediği saptanmıștır. $\mathrm{Bu}$ durumun nedenlerinin aydınlatılması için konuyla ilgili daha fazla sayıda hekimle çalışmaların yapılması gerekmektedir.

\section{KAYNAKLAR}

1. Maslach C, Jackson SE: The measurement of experienced burnout. Journal of Occupational Behavior, 1981; 2: 99-113.

2. Shanafelt TD, Balch CM, Bechamps GJ, Russell T, Dyrbye L at all: Burnout and career satisfaction among American surgeons. Ann Surg. $2009 ; 250$ (3): 463-71

3. Mollaoğlu M, Yılmaz M, Kars T: Hemșirelerde Tükenmişlik Sendromu. Toplum ve Hekim Dergisi 2003; 18 (4): 288- 293.

4. Oğuzberk M: Ruh Sağlı̆ğ Çalışanlarında Tükenmişlik. Klinik Psikiatri Dergisi 2008; 11: 167-179.

5. Ergin C: Maslach Tükenmişlik Ölçeğinin Türkiye Sağlık Personeli Normları. 3P Dergisi 1996; 4: 28-33

6. Aslan H, Gürkan BS, Alparslan N ve ark.: Tıpta uzmanlık ögrencisi hekimlerde tükenme düzeyleri, Türk Psikiyatri Dergisi 1996; 7(1): 39-45.

7. Arslan H, Ünal M, Aslan O, Gürkan S, Alpaslan N: Pratisyen Hekimlerde Tükenme Düzeyleri. Düşünen Adam, 1996; 3: 9.

8. Shanafelt TD, Balch CM, Bechamps GJ, Russell T, Dyrbye L at all: Burnout and medical errors among American surgeons. Ann Surg. 2010 Jun; 251(6): 995-1000.

9. Belcastro PA: Burnout and its relationship to teachers somatic complaints and illnesses. Psychol Rep. 1982; 50: 1045-1046.

10. Darell A Campbell, Jr MD: Burnout Among American Surgeons Central Surgical Association, Surgery 2001; 130: 4: 696-705.
11. Çam MO: Tükenmişlik, İzmir: Saray Medikal Yayıncılı. 1995.

12. Maslach C. A multidimensional theory of burnout. In Cooper, C.L. (Ed.), Theory of organizational stress; New York: Oxford University Press. 1998; 68: 86.

13. Maslach C, Schaufeli WB and Leiter MP: "Job Burnout" Annual Reviews of Psychology, 2001 ;52: 397-422.

14. Maslach C, Jackson SE: Maslach Burnout Inventory Manual (2nd Ed.), Palo Alto, Ca: Consulting Psychologist Press.; 1986; 1319-1326.

15. Torun A: "Stres ve Tükenmişlik", Endüstri ve Örgüt Psikolojisi içinde, Ed. Suna Tevrüz, 2. Baskı, Türk Psikologlar Derneği ve Kalite Derneği Ortak Yayını, İstanbul, 1997: 43-53.

16. Budak G ve Süregevil O: "Tükenmişlik ve Tükenmişliği Etkileyen Örgütsel Faktörlerin Analizine ilişkin Akademik Personel Üzerinde Bir Uygulama", Dokuz Eylül Üniversitesi Iktisadi ve İdari Bilimler Fakültesi Dergisi 2005; 20: 2: 95-108.

17. Cordes CL, Dougherty TW: "A Review and in Integration of Research on Job Burnout", Academy of Management Review 1993; 18: 4: 621-656.

18. Cordes CL, Dougherty TW, Michael B: "Pattens of Burnout Among Managers and Professionals: a Comparison of Models", Journal of Organizational Behavior, 1997; 18: 685701

19. Ardı̨ K, Polatcı S. Tükenmişlik Sendromu ve Madalyonun Öbür Yüzü. Ege Üniversitesi İktisadi ve İdari Bilimler Fakültesi Dergisi 2009: 21-46.

20. Randall M, WA Scott: "Burnout, Job Satisfaciton and Job Performance", Australian Psychologist 1988; 23: 3: 335-47.

21. Ensari H, Tuzcuoğlu S: "Marmara Üniversitesine Bağlı Fakültelerde Görev Yapan Yönetici ve Öğretim Elemanlarının Meslekten Yılgınlıklarında Kişilik Özelliklerinin Rolü”, Öneri Dergisi 1995; 2: 11: 51-63.

\section{Editörün Notu:}

Konuyla ilgili bir kaynak kullanıcıların yararına sunulmuştur:

Demir F, Ay P, Erbaş M, Özdil M, Yaşar E. İstanbul'da bir eğitim hastanesinde çalışan upta uzmanlık ögrencilerinde depresyon yaygınlığı ve ilişkili etkenler. Türk Psikiyatri Derg 2007; 18(1): 31-7.

\section{iLETIŞIM}

Dr. Hüseyin Can

Batman Verem Savaș Dispanseri

Batman Bölge Hastanesi BATMAN

e-posta: drhuseyincan@hotmail.com

Cep: 05306927878
Başvuru : 18.06.2010

Kabul : 18.08 .2010 